\title{
Good Corporate Governance, Motivasi, Gaya Kepemimpinan dan Kinerja Karyawan
}

\author{
Ni Kadek Ari Kusna Yanthi ${ }^{1}$ \\ Fakultas Ekonomi dan Bisnis \\ Universitas Udayana, Indonesia
}

\author{
I Wayan Pradnyantha Wirasedana ${ }^{2}$ \\ Fakultas Ekonomi dan Bisnis \\ Universitas Udayana, Indonesia
}

\begin{abstract}
Surel : kusnayanthi.ari@gmail.com
\section{ABSTRAK}

Bank BPD Bali adalah bank umum yang bergerak di sektor perbankan. Pencapaian target kredit Bank BPD Bali tidak lepas dari kinerja karyawan, karena dengan maksimalnya kinerja karyawan maka target yang ditetapkan akan tercapai. Penelitian ini bertujuan untuk mengetahui pengaruh GCG, motivasi, dan gaya kepemimpinan pada kinerja karyawan Bank BPD Bali di Kabupaten Badung. Populasi yang digunakan dalam penelitian ini sebanyak 2 unit kantor cabang dan 7 unit kantor cabang pembantu di Kabupaten Badung dengan penentuan sampel menggunakan metode purposive sampling, jumlah sampel adalah 57 responden. Teknik analisis data yang digunakan adalah anlisis linear berganda. Berdasarkan hasil penelitian menunjukkan bahwa GCG, motivasi, dan gaya kepemimpinan berpengaruh positif pada kinerja karyawan Bank BPD Bali di Kabupaten Badung, dengan menerapkan Good Corporate Governance, motivasi dan gaya kepemimpinan akan meningkatkan kinerja karyawan.
\end{abstract}

Kata Kunci: Good Corporate Governance; Motivasi; Gaya Kepemimpinan; Kinerja Karyawan.

\section{Good Corporate Governance, Motivation, Leadership Style and Employee Performance}

\begin{abstract}
$B P D$ Bali's bank is a commercial bank engaged in the banking sector. The achievement of Bank BPD Bali's credit targets cannot be separated from employee performance, because with the maximum performance of employees the target set will be achieved. This study aims to determine the effect of GCG, motivation, and leadership style on the performance of employees of Bank BPD Bali's in Badung Regency. The populations used in this study were 2 branch offices and 7 sub-branch offices in Badung Regency with the determination of the sample using purposive sampling method, the total sampels was 57 respondents. The data analysis technique is multiple linear analysis. The results of the study showed that GCG, motivation, and leadership style had a positive effect on the performance of the employees of Bank BPD Bali's in Badung Regency, by implementing Good Corporate Governance, motivation and leadership style will improve employee performance.
\end{abstract}

Keywords: $\quad$ Good Corporate Governance; Motivation; Leadership Style; Employee Performance.

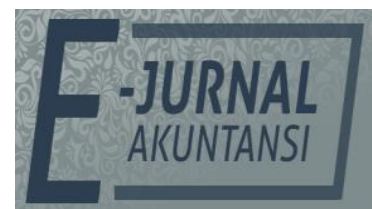

e-ISSN 2302-8556

Vol. 31 No. 4

Denpasar, April 2021

Hal. 909-924

DOI:

10.24843/EJA.2021.v31.i04.p09

PENGUTIPAN:

Yanthi, N.K.A.K., \&

Wirasedana, I W.P.W. (2021).

Good Corporate Governance,

Motivasi, Gaya

Kepemimpinan dan Kinerja

Karyawan. E-Jurnal

Akuntansi, 31(4), 909-924

RIWAYAT ARTIKEL:

Artikel Masuk:

10 Januari 2020

Artikel Diterima:

19 Februari 2021

Artikel dapat diakses : https://ojs.unud.ac.id/index.php/Akuntansi/index 


\section{PENDAHULUAN}

Sumber daya manusia menjadi aspek yang paling penting dalam sebuah keberhasilan di perusahaan untuk mencapai tujuan. Perusahaan melakukan perubahan sangat tergantung pada kemampuan karyawan dalam menjalankan perubahan tersebut. Tingginya tingkat kompetisi bisa memicu setiap perusahaan untuk mempertahankan kelangsungan hidupnya melaui memberikan perhatian yang lebih pada aspek sumber daya manusia. Karyawan merupakan aset berharga yang dimiliki perusahaan dan juga aspek penting dalam kelangsungan sebuah organisasi, dimana keberhasilan suatu perusahaan dipengaruhi oleh kenyamanan yang dirasakan karyawan saat bekerja dan berdampak pada kinerja karyawan.

Perbankan merupakan salah satu perusahaan yang memiliki peran penting bagi kelangsungan perekonomian. Perbankan mempunyai peranan yang besar dalam mendorong perekonomian nasional, kerena sebagai lembaga keuangan bank memiliki usaha pokok berupa menghimpun dana dan kemudian menyalurkan kembali kepada masyarakat untuk jangka waktu tertentu. Sarana perbankan di daerah sebagai lembaga usaha perbankan, harus menghadapi persaingan antar bank, baik itu bank umum maupun bank swasta dalam cakupan mutu pelayanan, efisiensi biaya, teknologi, citra bank, dan pelayanan perbankan. Kemajuan untuk bersaing dan memiliki keunggulan dari bank-bank lainnya perlu pemenuhan sumber daya manusia yang optimal, karena sumber daya manusia akan selalu mengikuti perkembangan jaman.

Tantangan tersendiri yang dihadapi perusahaan perbankan dalam upaya meningkatkan kualitas perusahaan, kususunya meningkatkan kinerja karyawannya adalah penerapan tata kelola perusahaan yang baik atau disebut dengan Good Corporate Governance (GCG), yang berlandasan pada Pedoman Good Corporate Governance Perbankan Indonesia. Tata kelola perusahaan dipandang sebagai proses dan struktur yang digunakan untuk mengarahkan dan mengelola bisnis urusan perusahaan menuju peningkatan kemakmuran bisnis dan akuntabilitas perusahaan dengan tujuan akhir dari merealisasikan nilai pemegang saham jangka panjang, sambil memperhitungkan kepentingan pemangku kepentingan lainnya (Ahmed \& Rugami, 2019). Forum for Corporate Governance in Indonesia (FCGI) tahun 2001 mendefinisikan corporate governance sebagai seperangkat peraturan yang mengatur hubungan antara pemegang, pengurus perusahaan, pihak kreditur, pemerintah, karyawan, serta pemegang kepentingan internal dan eksternal lainnya yang berkaitan dengan hak-hak dan kewajiban mereka atau dengan kata lain suatu sistem yang mengendalikan perusahaan. lain suatu sistem yang mengendalikan perusahaan.

Selain faktor GCG, mengelola sumber daya manusia pada perusahaan tidak terlepas dri faktor motivasi yang diberikan untuk karyawan dalam organisasi yang bersangkutan. Motivasi merupakan faktor penting bagi suatu perusahaan untuk mendorong kinerja karyawannya sehingga tujuan atau sasaran yang telah ditetapkan oleh perusahaan dapat terwujudkan (N. K. D. Y. Putri \& Putra, 2017). Seorang karyawan yang termotivasi akan bersifat energik dan bersemangat, secara tidak langsung memengaruhi kinerja yang tercipta baik dan tujuan perusahaan akan tercapai. Sebaliknya, jika seorang karyawan yang motivasinya rendah akan memiliki rasa tidak nyaman dan tidak senang terhadap 
pekerjaannya dan secara tidak langsung menciptakan kinerja mereka menjadi buruk yang berdampak pada tujuan perusahaan tidak akan tercapai.

Bank umum yang bergerak di sektor perbankan dan menjadi perusahaan daerah salah satunya adalah PT. Bank Pembangunan Daerah Bali (Bank BPD Bali). Bank BPD Bali sebagai Bank Daerah Provinsi Bali yang mengemban misi menjadi pendukung program pembangunan ekonomi daerah serta meningkatkan kualitas sumber daya manusia dan memenuhi harapan stakeholder. Upaya yang telah dilakukan yaitu program transformasi Bank BPD Bali melalui penguatan daya saing dan kelembagaan Bank BPD Bali. Program transformasi tersebut diharapkan bisa lebih efektif melaksanakan fungsinya sebagai agent of development di daerah. Bank BPD Bali saat ini menempati posisi yang penting dalam perekonomian mengingat banyaknya permintaan peminjaman dana untuk modal usaha, investasi, pendidikan dan lain-lain.. Bank BPD Bali memiliki 1 kantor pusat dan 13 kantor cabang yang tersebar diseluruh kabupaten yang ada di Provinsi Bali. Jumlah kantor cabang Bank BPD Bali yang tersebar di Provinsi Bali beserta total aset periode Desember 2018 dapat dilihat pada Tabel 1.

Tabel 1. Jumlah Kantor Cabang dan Cabang Pembantu serta Total Aset per Desember 2018

\begin{tabular}{|c|c|c|c|c|}
\hline No & $\begin{array}{c}\text { Nama } \\
\text { Kota/Kabupaten }\end{array}$ & $\begin{array}{c}\text { Jumlah Kantor } \\
\text { Cabang }\end{array}$ & $\begin{array}{c}\text { Jumlah Kantor } \\
\text { Cabang } \\
\text { Pembantu }\end{array}$ & Total Aset \\
\hline 1 & Kota Denpasar & 2 & 10 & Rp.8.236.392.000 \\
\hline 2 & Kab. Badung & 2 & 7 & Rp.3.567.240.000 \\
\hline 3 & Kab. Buleleng & 2 & 2 & Rp.2.306.916.000 \\
\hline 4 & Kab. Tabanan & 1 & 7 & Rp.1.905.817.000 \\
\hline 5 & Kab. Gianyar & 2 & 3 & Rp.1.800.338.000 \\
\hline 6 & Kab. Karangasem & 1 & 4 & Rp.1.279.515.000 \\
\hline 7 & Kab. Jembrana & 1 & 2 & Rp.1.014.722.000 \\
\hline 8 & Kab. Klungkung & 1 & 1 & Rp.1.000.865.000 \\
\hline 9 & Kab. Bangli & 1 & 1 & Rp.969.645.000 \\
\hline & Jumlah & 13 & 37 & Rp.22.081.450.000 \\
\hline
\end{tabular}

Sumber: Bank Pembangunan Daerah Bali, 2019

Berdasarkan data pada Tabel 1, jumlah kantor cabang dan kantor cabang pembantu (capem) Bank BPD Bali di Provinsi Bali periode Desember 2018 berjumlah 13 kantor cabang dan 37 kantor capem yang tersebar di 9 Kabupaten/Kota di Bali. Kabupaten Badung sendiri terdapat 2 kantor cabang dan 7 kantor capem, dan memiliki total aset sampai dengan periode Desember 2018 yaitu sebesar Rp3.567.240.000. Total aset yang dimiliki oleh BPD Bali Cabang Badung menempati peringkat kedua setelah BPD Bali Cabang Kota Denpasar dengan total aset periode Desember 2018 sebesar Rp8.236.392.000. Mengingat perkembangan ekonomi yang sangat pesat di Bali berada di Kabupaten Badung. Hal ini dapat dilihat dari fasilitas publik dan swasta yang dimiliki seperti bandara, hotel-hotel berbintang dan segala jenis usaha mikro, kecil, dan menengah (UMKM). Bank BPD Bali Cabang Badung walaupun jumlah kantor cabang dan capem yang tersebar di kabupaten ini hampir setara dengan Kota Denpasar nyatanya belum mampu menghasilkan total aset yang sebanding dengan total aset Bank BPD Bali Cabang Denpasar, hal ini dikarenakan 
peningkatan pertumbuhan dana pihak ketiga dan penyaluran kredit berpusat di Denpasar yang merupakan pusat kota dan perekonomian di Provinsi Bali.

Menurut Nasution (2018) dalam menjalankan fungsi utama bank yaitu untuk memobilasi dana masyarakat dan menyalurkan dana tersebut dalam bentuk kredit kepada pengguna atau investasi yang efektif dan efisien, perlu didukung peraturan yang cukup dan dikaitkan dengan prinsip-prinsip GCG. Kelemahan yang sering dialami dalam pemberian kredit, contohnya seperti pemberian kredit tanpa melalui proses analisa kredit yang sehat, konsentrasi kredit yang berlebihan kepada suatu kelompok usaha, dan lemahnya aspek supervise dan regulasi perbankan. Kelemahan-kelemahan pemberian kredit ini tidak terkecuali dialami oleh Bank BPD Bali, mengingat isu yang terjadi pada tahun 2017 yaitu Bank BPD Bali mengakui mengalami kredit macet sebesar Rp. 179.000.000.000 dari 2 debitur yang telah dinyatakan pailit (Artikel Bisnis.com). Pencapaian target kredit Bank BPD Bali yang terseber di Provinsi Bali dapat dilihat pada Tabel 2.

Tabel 2. Pencapaian Target Kredit PT.Bank Pembangunan Daerah Bali per Desember 2018

\begin{tabular}{llrrr}
\hline No & \multicolumn{1}{c}{ Nama } & Realisasi Tahun & Target Tahun & \multicolumn{1}{c}{ Realisasi Tahun } \\
& Kota/Kabupaten & \multicolumn{2}{c}{ 2017 } & \multicolumn{1}{c}{2018} \\
\hline 1 & Kota Denpasar & Rp.3.322.619.000 & Rp.3.638.268.000 & Rp.3.367.329.000 \\
2 & Kab. Buleleng & Rp.2.250.125.000 & Rp.2.404.829.000 & Rp.2.264.683.000 \\
3 & Kab. Badung & Rp.2.185.156.000 & Rp.2.338.854.000 & Rp.2.139.294.000 \\
4 & Kab. Tabanan & Rp.1.851.384.000 & Rp.2.027.265.000 & Rp.1.842.106.000 \\
5 & Kab. Gianyar & Rp.1.488.548.000 & Rp.1.629.960.000 & Rp.1.455.791.000 \\
6 & Kab. Karangasem & Rp.1.286.288.000 & Rp.1.337.940.000 & Rp.1.263.727.000 \\
7 & Kab. Bangli & Rp.913.359.000 & Rp.1.000.128.000 & Rp.929.365.000 \\
8 & Kab.Klungkung & Rp.911.215.000 & Rp.997.780.000 & Rp.935.735.000 \\
9 & Kab. Jembrana & Rp.888.286.000 & Rp.972.674.000 & Rp.931.254.000 \\
& Jumlah & Rp.15.096.980.000 & Rp.16.347.698.000 & Rp.15.129.284.000 \\
\hline
\end{tabular}

Sumber: Bank Pembangunan Daerah Bali, 2019

Pencapaian target kredit cabang-cabang tidak lepas dari kinerja karyawan itu sendiri karena dengan maksimalnya kinerja dari karyawan maka akan tercapainya target-target yang diberikan sehingga berdampak kualitas kredit yang dihasilkan dari kantor cabang tersebut. Berdasarkan Tabel 2, terlihat Bank BPD Bali di Kabupaten Badung menduduki posisi ketiga setelah Kota Denpasar dan Kabupaten Buleleng. Kabupaten Badung jika disimak dari daerahnya, merupakan daerah wisatawan sehingga banyaknya wirausaha di wilayah Badung yang bepotensi dalam market share produk Bank BPD Bali dalam pencapaian target-target Bank BPD Bali. Fenomena pencapaian kinerja karyawan Bank BPD Bali Cabang Badung menduduki posisi ketiga apakah diakibatkan oleh GCG, motivasi, dan gaya kepemimpinan. Atas dasar tersebut yang melatar belakangi pemilihan Bank BPD Bali Cabang Badung sebagai tempat penelitian.

Beberapa penelitian terdahulu diantaranya Amri et al. (2016) yaitu ada pengaruh positif dari variabel GCG terhadap kinerja karyawan. Hasil penelitian tersebut sejalan dengan penelitian (Mahadewi \& Putri, 2019), (Sitio \& Anisykurlillah, 2014), serta (Gunawan \& Sutiono, 2018) bahwa GCG dan penerapan prinsip-prinsip GCG berpengaruh positif terhadap kinerja. Penelitian Sari et al. (2016) memperoleh hasil bahwa penerapan motivasi berpengaruh 
positif terhadap kinerja karyawan. Hasil penelitian tersebut sejalan dengan penelitian yang dilakukan oleh Sidanti (2015) serta Putri \& Badera (2019) menyatakan bahwa motivasi berpengaruh positif terhadap kinerja. Hasil penelitian yang dilakukan oleh (Junaidi \& Susanti, 2006), Noviani \& Widhiyani (2018), dan Sari (2015) yang menyatakan bahwa gaya kepemimpinan berpengaruh positif terhadap kinerja.

Berdasarkan yang dijelaskan dalam latar belakang, maka peneliti membuat sebuah penelitian tentang "Pengaruh GCG, Motivasi, dan Gaya Kepemipinan Pada Kinerja karyawan PT. Bank Pembangunan Daerah Bali di Kabupaten Badung".

Tujuan penelitian ini adalah: 1) memperoleh bukti empiris mengenai pengaruh GCG pada kinerja karyawan Bank BPD Bali di Kabupaten Badung, 2) memperoleh bukti empiris mengenai pengaruh Motivasi pada kinerja karyawan Bank BPD Bali di Kabupaten Badung dan 3) memperoleh bukti empiris mengenai Gaya Kepemimpinan pada kinerja karyawan Bank BPD Bali di Kabupaten Badung.

Teori agensi merupakan teori yang dibangun berdasarkan pada hubungan keagenan antara agent dan principal (Jensen \& Meckling, 1976). Suatu perjanjian antara satu atau lebih pihak prinsipal yang mempekerjakan agen, agen tersebut diharapkan dapat melakukan beberapa layanan atas nama prinsipal, merupakan definisi dari hubungan keagenan. Principal diartikan sebagai pihak yang memberikan amanat kepada agent untuk melakukan suatu jasa atas nama principal, sedangkan agent diartikan sebagai pihak yang memberi mandat yang demikian atau agent bertindak sebagai pihak yang mengevaluasi informasi. Menurut Putri \& Putra (2017) dilihat dari sudut pandang teori agensi, principal (pemilik atau manajemen puncak) membawahi agent (karyawan atau manajer yang lebih rendah) untuk melaksanakan kinerja yang lebih efisien.

Hubungan keagenan dalam suatu perusahaan, yaitu hubungan antara pemegang saham dan manajemen perusahaan. Puspitha dan Sujana (2016) menyatakan bahwa agen diasumsikan sebagai pihak yang berwenang untuk melakukan pengelolaan dan pengambilan kepuutusan berkaitan dengan perusahaan atas nama pemilik. Menurut Clemente \& Labat (2009) corporate governance merupakan salah satu mekanisme pengendalian internal yang paling penting dari masalah lembaga dalam mengurangi salah satu dampak dari hubungan keagenan yaitu asimetri informasi.

Setyawan \& Putri (2013) melakukan penelitian tentang pengaruh GCG terhadap kinerja keuangan LPD. Hasil analisis menunjukkan bahwa penerapan GCG memberikan pengaruh yang positif dan signifikan terhadap kinerja keuangan LPD. Semakin baik penerapan GCG maka kinerja keuangannya akan mengalami peningkatan. Penelitian tersebut selaras dengan hasil penelitian yang dilakukan oleh Pratiwi \& Budiartha (2018) yang menghasilkan bahwa penerapan GCG berpengaruh positif dan signifikan terhadap kinerja. Hal tersebut serupa dengan hasil penelitian Syah et al. (2018), Dewi \& Wirasedana (2018), Dewi \& Tenaya (2017) serta Tertius \& Christiawan (2015) menyatakan GCG berpengaruh positif pada kinerja, hal ini mengindikasikan bahwa penerapan tata kelola perusahaan yang baik mencerminkan bahwa perusahaan tidak mengalami permasalahan terutama pada kinerjanya. 
Konsep GCG diterapkan dalam sebuah perusahaan dapat memperbaiki kinerja Sumber Daya Manusia (SDM) yang sebelumnya kurang baik menjadi lebih baik. Hal ini dilakukan melalui transformasi nilai-nilai yang terkandung dalam prinsip GCG ke dalam kegiatan sehari-hari karyawan dan jajaran manajemen perusahaan. Perilaku setiap individu yang mengarah pada kinerjanya dipengaruhi oleh nilai-nilai GCG tersebut. Berdasarkan uraian, maka rumusan hipotesis yang diajukan sebagai berikut.

$\mathrm{H}_{1}$ : GCG berpengaruh positif pada kinerja karyawan.

Motivasi secara sederhana dapat diartikan sebagai tindakan atau kondisi yang mendorong seseorang untuk melakukan sebuah kegiatan atau pekerjaan semaksimal mungkin untuk berbuat dan berproduksi. Menurut Shahzadi et al ( 2014) motivasi karyawan sangat penting bagi organisasi karena setiap masalah memerlukan fisik, keuangan dan sumber daya manusia untuk mencapai tujuan. Melalui motivasi, sumber daya manusia dapat dimanfaatkandengan memanfaatkan sepenuhnya itu. Ini bisa dilakukan dengan membangun kemauan karyawan untuk bekerja.

Beberapa penelitian mengaitkan pengaruh motivasi pada kinerja karyawan, antara lain Juniantara \& Riana (2015) menyatakan bahwa motivasi berpengaruh positif dan signifikan terhadap kinerja karyawan, artinya motivasi bahwa semakin baik dan meningkat motivasi yang diberikan pada kepada karyawan maka kepuasan kerja karyawan akan meningkat. Hasil tersebut didukung oleh penelitian Kesuma \& Syamsuddin (2019) serta Gultom (2014) memperoleh bahwa motivasi berpengaruh positif terhadap kinerja karyawan. Hal ini sejalan dengan penelitian Karma et al. (2017), Tulhusnah et al. (2018), serta Nurcahyani \& Adnyani (2016) yang menghasilkan motivasi berpengaruh positif terhadap kinerja.

Perusahaan dapat memotivasi karyawan agar dapat menyelesaikan pekerjaan dengan tepat waktu dan sesuai dengan standar organisasi serta mendorong untuk mengembangkan potensi dan meningkatkan kariernya di perusahaan. Dari uraian, maka rumusan hipotesis yang diajukan sebagai berikut. $\mathrm{H}_{2}$ : Motivasi berpengaruh positif pada kinerja karyawan

Gaya kepemimpinan ini menjelaskan bagaimana seorang pemimpin mampu melakukan penyesuaian diri dengan kematangan bawahan dan lingkungan kerja perusahaan. Kepemimpinan memiliki peran penting untuk mempengaruhi cara kinerja karyawannya, dimana kepemimpinan secara tidak langsung memberikan dampak positif dan negatif terhadap kinerja karyawan yang dipimpinnya. Karakter seorang karyawan harus dipelajari oleh seorang pemimpin untuk dapat mengevaluasi dirinya dan mengetahui kepemimpinannya telah sesuai dengan kemauan, kemampuan maupun harapan karyawannya. Kepemimpinan yang sudah sesuai dengan harapan karyawan akan memberikan peran besar dalam kemajuan suatu organisasi.

Penelitian yang dilakukan oleh Setiawan \& Mujiati (2016) mengenai pengaruh gaya kepemimpinan terhadap kinerja karyawan pada PT. Astra Honda. Mendapatkan hasil bahwa gaya kepemimpinan berpengaruh positif dan signifikan terhadap kinerja karyawan pada PT. Astra Honda, apabila gaya kepemimpinan berperilaku teladan bagi karyawannya maka kinerja karyawan di PT.Astra Honda akan meningkat secara signifikan. Hal ini didukung oleh 
penelitian Dewi \& Mujiati (2015) dan Wiguna (2015) menghasilkan gaya kepemimpinan berpengaruh positif terhadap kinerja karyawan.

Sejalan dengan hasil penelitian Sudja \& Mujiati (2017) serta Cahyani \& Mulyadi (2017) yang menghasilkan gaya kepemimpinan berpengaruh signifikan pada kinerja. Hal ini menandakan bahwa semakin tinggi gaya kepemimpinan yang diberikan pada karyawan maka kinerja karyawan akan mengalami peningkatan. Berdasarkan uraian, maka rumusan hipotesis yang diajukan sebagai berikut.

$\mathrm{H}_{3}$ : Gaya Kepemimpinan berpengaruh positif pada kinerja karyawan.

\section{METODE PENELITIAN}

Penelitian ini menggunakan pendekatan kuantitatif berbentuk asosiatif. Penelitian ini dilakukan di Bank BPD Bali Kabupaten Badung. Jenis data yang digunakan dalam penelitian ini adalah data kualitatif yang berupa nama, gambaran umum, dan struktur organisasi Bank BPD Bali Kabupaten Badung, dan data kuantitatif yang berupa daftar pernyataan-pernyataan yang terdapat dalam kuesioner dan gambaran umum, sejarah singkat serta struktur organisasi Bank BPD Bali Kabupaten Badung. Sumber data dalam penelitian adalah sumber data primer meliputi hasil jawaban responden yang diperoleh secara langsung melalui kuisioner yang dibagikan pada setiap responden Bank BPD Bali di Kabupaten Bdung, dan sumber data sekunder meliputi data jumlah aset, dan jumlah karyawan Bank BPD Bali.

Populasi dalam penelitian ini adalah Bank BPD Bali di Kabupaten Badung yang berjumlah 2 unit cabang dan 7 cabang pembantu sesuai dengan data yang diperoleh dari Bank BPD Bali periode Desember 2018. Sampel adalah bagian dari jumlah dan karakteristik yang dimiliki oleh populasi (Sugiyono, 2017:81). Teknik penentuan sampel pada penelitian ini menggunakan metode purposive sampling, yaitu teknik pengambilan sampel dengan pertimbangan atau kriteria tertentu (Sugiyono, 2013:122). Adapun kriterianya adalah sebagai berikut: 1) Karyawan yang bekerja di bidang kredit, dan 2) Karyawan yang bekerja di bidang Hukum Administrasi Kredit (HAK). Setelah ditetapkan kriteria penentuan sampel, didapatkan hasil sampel sebanyak 57 responden dari 2 unit cabang dan 7 cabang pembantu yang tersebar di Kabupaten Badung.

Metode pengumpulan data yang digunakan dalam penelitian ini adalah dengan menggunakan kuisioner, yaitu teknik pengumpulan data yang dilakukan dengan memberikan seperangkat pertanyaan atau pernyataan tertulis kepada responden untuk dijawab. Kuisioner disebarkan langsung kepada responden yang telah ditentukan di Bank BPD Bali Kabupaten Badung. Teknik analisis data yang digunakan dalam penelitian ini yaitu teknik analisis linear berganda yang bertujuan untuk mengetahui gambaran mengenai pengaruh variabel bebas (GCG, motivasi, dan gaya Kepemimpinan) terhadap variabel terikat (kinerja karyawan).

\section{HASIL DAN PEMBAHASAN}

Penelitian ini dilakukan untuk menguji pengaruh GCG, motivasi, dan gaya kepemimpinan pada kinerja karyawan Bank BPD Bali di Kabupaten Badung. Data dikumpulkan dengan menyebarkan kuisioner ke 2 kantor cabang utama 
dan 7 kantor cabang pembantu yang tersebar di Kabupaten Badung. Adapun rincian penyebaran kuisioner dapat dilihat pada Tabel 3, sebagai berikut.

Tabel 3. Perincian Pengembalian dan Penggunaan Kuisioner

\begin{tabular}{ll}
\hline Uraian & $\begin{array}{l}\text { Jumlah } \\
\text { kuisioner }\end{array}$ \\
\hline Total Kuisioner yang disebar & 57 \\
Kuisioner yang dikembalikan & 54 \\
Kuisioner yang gugur (tidak bekerja di bidang kredit dan HAK) & 0 \\
Kuisioner yang digunakan & 54 \\
Tingkat Pengembalian (response rate) $=54 / 57 \times 100 \%$ & $94,7 \%$ \\
Tingkat penggunaan (usable respon rate) $=54 / 57 \times 100 \%$ & $94,7 \%$ \\
\hline
\end{tabular}

Sumber: Data Penelitian, 2019

Berdasarkan Tabel 3, dapat dilihat bahwa jumlah kuisioner yang disebar pada awalnya sebanyak 57 eksemplar. Jumlah ini didapat setelah melakukan survei pendahuluan yang dilakukan ke masing-masing Bank BPD Bali Kabupaten Badung yaitu Bank BPD Bali Cabang Mangupura dan Bank BPD Bali Cabang Kuta. Setelah diperiksa, kuisioner yang kembali sebanyak 54 eksemplar, tidak terdapat kuisioner yang tidak memenuhi kriteria bekerja di bidang kredit dan bidang Hukum Administrasi Kredit (HAK) atau kuisioner yang digugurkan, sehingga semua kuisioner yang kembali layak digunakan untuk penelitian.

Uji validitas merupakan pengujian instrument penelitian sebagai suatu derajat ketepatan alat ukur penelitian tentang inti atau arti sebenarnya yang diukur. Suatu kuisioner dikatakan validitas apabila memenuhi syarat minimum suatu kuisioner, yaitu jika korelasi antara butir dengan skor total tersebut positif dan nilainya lebih dari 0,30 dengan tingkat kesalahan Alpha 0,05. Hasil uji validitas pada Tabel 3, menunjukkan bahwa seluruh variabel memiliki nilai koefisien korelasi dengan skor total seluruh item pernyataan telah lebih besar dari 0,30 . Hal ini menunjukkan bahwa butir-butir pernyataan seluruhnya dalam instrument penelitian tersebut valid.

Reliabilitas merupakan derajat ketepatan, ketelitian atau keakuratan yang ditunjukkan oleh instrument pengukuran dimana pengujiannya dapat dilakukan secara internal, yaitu pengujian dengan menganalisis konsistensi butir-butir yang ada. Suatu instrument dikatakan reliabel apabila instrument tersebut memiliki nilai Cronbach Alpha lebih dari 0,70. Adapun hasil dari uji reliabilitas dapat ditunjukkan pada Tabel 4, sebagai berikut.

Tabel 4. Hasil Uji Reliabilitas

\begin{tabular}{llll}
\hline No & Variabel & Cronbach's Alpha & Keterangan \\
\hline 1 & Good Corporate Governance $\left(\mathrm{X}_{1}\right)$ & 0,953 & Reliabel \\
2 & Motivasi $\left(\mathrm{X}_{2}\right)$ & 0,852 & Reliabel \\
3 & Gaya Kepemimpinan $\left(\mathrm{X}_{3}\right)$ & 0,855 & Reliabel \\
4 & Kinerja Karyawan $(\mathrm{Y})$ & 0,899 & Reliabel \\
\hline
\end{tabular}

Sumber: Data Penelitian, 2019

Hasil uji reliabilitas yang disajikan dalam Tabel 4 menunjukkan bahwa seluruh instrument penelitian yaitu GCG, Motivasi, Gaya Kepemimpinan, dan Kinerja Karyawan memiliki koefisien Cronbach Alpha lebih dari 0,70. Dengan demikian dapat dikatakan semua instrumen reliabel sehingga dapat digunakan untuk melakukan penelitian. 
Uji normalitas bertujuan untuk mengetahui apakah residual dari model regresi yang dibuat berdistribusi normal atau tidak. Untuk menguji apakah data yang digunakan normal atau tidak, dapat dilakukan dengan menggunakan uji Kolmogorov-Sminorv. Apabila koefisien Asymp.Sig.(2-tailed) lebih besar dari 0,05 maka data tersebut dikatakan berdistribusi normal. Berdasarkan Tabel 4.8, dapat dilihat bahwa nilai Asymp.Sig.(2-tailed) sebesar 0,438. Hasil tersebut mengindikasikan bahwa model persamaan regresi tersebut berdistribusi normal karena Asymp.Sig.(2-tailed) 0,438 lebih besar dari nilai alpha 0,05.

Uji multikolinearitas bertujuan untuk menguji apakah di dalam model regresi ditemukan adanya korelasi antar variabel-variabel bebas. Berdasarkan hasil penelitian ini menunjukkan bahwa nilai tolerance dan VIP dari variabel GCG, motivasi, dan gaya kepemimpinan. Nilai tersebut menunjukkan bahwa nilai tolerance untuk setiap variabel lebih besar dari 10\% dan nilai VIP lebih kecil dari 10 yang berarti model persamaan regresi bebas dari multikolinearitas.

Uji heteroskedastisitas bertujuan untuk menguji model regresi apakah terjadi ketidaksamaan varian dari residual satu pengamatan ke pengamatan lain. Uji ini dapat dianalisis melalui uji glejser dengan melihat tingkat signifikansi, jika tingkat signifikansi berada di atas 0,05 maka model regresi ini bebas dari masalah heteroskedastisitas. Pada hasil penelitian ini dapat dilihat bahwa nilai signifikansi dari variabel GCG, motivasi, dan gaya kepemimpinan masingmasing sebesar 0,573,0,057, dan 0,104. Nilai tersebut lebih besar dari 0,05 yang berarti tidak dapat pengaruh antara variabel terhadap absolute residual, dengan demikian model yang dibuat tidak mengandung gejala heteroskedastisitas.

Analisis statistik deskriptif memberikan gambaran atau deskripsi suatu data yang dilihat dari besarnya nilai minimum, maksimum, mean, dan simpangan baku (standard devation) dengan $\mathrm{N}$ merupakan banyaknya responden penelitian. Hasil analisis statistik deskriptif dapat dilihat pada tabel sebagai berikut.

Tabel 5. Statistik Deskriptif

\begin{tabular}{lccccc}
\hline \multicolumn{1}{c}{ Variabel } & $\mathrm{N}$ & Minimum & Maximum & Mean & $\begin{array}{c}\text { Std. } \\
\text { Deviation }\end{array}$ \\
\hline $\begin{array}{l}\text { Good Corporate Governance } \\
\left(\mathrm{X}_{1}\right)\end{array}$ & 54 & 2,95 & 4,85 & 3,9630 & 0,52577 \\
Motivasi $\left(\mathrm{X}_{2}\right)$ & 54 & 3,00 & 5,00 & 4,2296 & 0,47648 \\
Gaya Kepemimpinan $\left(\mathrm{X}_{3}\right)$ & 54 & 2,80 & 5,00 & 4,1037 & 0,53516 \\
Kinerja Karyawan $(\mathrm{Y})$ & 54 & 2,75 & 5,00 & 4,1157 & 0,62893 \\
\hline
\end{tabular}

Sumber: Data Penelitian, 2019

Variabel good corporate governance memiliki nilai minimum sebesar 2,95 sedangkan nilai maximum sebesar 4,85. Mean dari good corporate governance sebesar 3,96. Nilai rata-rata good corporate governance lebih mendekati nilai maximum, hal ini berarti penerapan good corporate governance cenderung tinggi. Standar deviasi sebesar 0,525 artinya terdapat perbedaan nilai good corporate governance yang diteliti terhadap nilai rata-ratanya sebesar 0,525.

Variabel motivasi memiliki nilai minimum sebesar 3,00 sedangkan nilai maximum sebesar 5,00. Mean dari motivasi sebesar 4,22. Nilai rata-rata motivasi lebih mendekati nilai maximum, hal in berarti penerapan motivasi cenderung 
tinggi. Standar deviasi sebesar 0,476 artinya terdapat perbedaan nilai motivasi yang diteliti terhadap nilai rata-ratanya sebesar 0,476.

Variabel gaya kepemimpinan memiliki nilai minimum sebesar 2,80 sedangkan nilai maximum sebesar 5,00. Mean dari gaya kepemimpinan sebesar 4,10. Nilai rata-rata gaya kepemimpinan lebih mendekati nilai maximum, hal ini berarti penerapan gaya kepemimpinan cenderung tinggi. Standar deviasi sebesar 0,535 artinya terdapat perbedaan nilai gaya kepemimpinan yang diteliti terhadap nilai rata-ratanya sebesar 0,535 .

Variabel kinerja karyawan memiliki nilai minimum sebesar 2,75 sedangkan nilai maximum sebesar 5,00. Mean dari kinerja karyawan sebesar 4,11. Nilai rata-rata kinerja karyawan lebih mendekati nilai maximum, hal ini berarti penerapan kinerja karyawan cenderung tinggi. Standar deviasi sebesar 0,628 artinya terdapat perbedaan nilai kinerja karyawan yang diteliti terhadap nilai rata-ratanya sebesar 0,628 .

Analisis regresi linear berganda digunakan untuk mengetahui ketergantungan satu variabel terikat hanya pada satu variabel bebas dengan atau tanpa variabel moderator, serta untuk mengetahui ketergantungan satu variabel terikat pada variabel-variabel bebas. Uji ini dilakukan untuk mengetahui besarnya pengaruh Good Corporate Governance $\left(X_{1}\right)$, Motivasi $\left(X_{2}\right)$, Gaya Kepemimpinan $\left(\mathrm{X}_{3}\right)$, dan Kinerja Karyawan $(\mathrm{Y})$.

Tabel 6. Hasil Uji Analisis Regresi Linear Berganda

\begin{tabular}{|c|c|c|c|c|c|}
\hline \multirow[b]{2}{*}{ Variabel } & \multicolumn{2}{|c|}{$\begin{array}{c}\text { Unstandardized } \\
\text { Coefficients }\end{array}$} & \multirow{2}{*}{$\begin{array}{c}\text { Standardized } \\
\text { Coefficients } \\
\text { Beta }\end{array}$} & \multirow[t]{2}{*}{$\mathrm{t}$} & \multirow[t]{2}{*}{ Sig. } \\
\hline & B & $\begin{array}{l}\text { Std. } \\
\text { Error }\end{array}$ & & & \\
\hline (constant) & $-0,565$ & 0,399 & & $-1,417$ & 0,163 \\
\hline GCG & 0,423 & 0,162 & 0,354 & 2,611 & 0,012 \\
\hline Motivasi & 0,344 & 0,155 & 0,261 & 2,218 & 0,031 \\
\hline Gaya Kepemimpinan & 0,377 & 0,157 & 0,321 & 2,408 & 0,020 \\
\hline Adjusted $R$ Square & & & & & 0,740 \\
\hline F Statistik & & & & & 51,152 \\
\hline Signifikansi & & & & & 0,000 \\
\hline
\end{tabular}

Sumber: Data penelitian, 2019

Berdasarkan hasil analisis regresi linear berganda seperti yang disajikan pada Tabel 6, maka persamaan regresinya adalah sebagai berikut.

$$
Y=-0,565+0,423 X_{1}+0,344 X_{2}+0,377 X_{3}+\varepsilon
$$

Nilai konstanta sebesar $-0,565$, berarti apabila GCG $\left(X_{1}\right)$, Motivasi $\left(X_{2}\right)$, dan Gaya Kepemimpinan $\left(X_{3}\right)$ bernilai nol, maka kinerja karyawan bernilai sebesar 0,565 satuan. Nilai koefisien regresi GCG $\left(X_{1}\right)$ sebesar 0,423, berarti jika GCG meningkat 1 satuan maka kinerja karyawan akan meningkat 0,423 satuan, dengan asumsi variabel motivas dan gaya kepemimpinan konstan. Hasil ini mengindikasikan bahwa GCG berbanding lurus dengan kinerja karyawan.

Nilai koefisien Motivasi $\left(\mathrm{X}_{2}\right)$ sebesar 0,344, berarti jika motivasi meningkat 1 satuan maka kinerja karyawan akan meningkat 0,344 satuan, dengan asumsi variabel GCG dan gaya kepemimpinan konstan. Hasil ini mengindikasikan bahwa motivasi berbanding lurus dengan kinerja karyawan. Nilai koefisien Gaya Kepemimpinan $\left(X_{3}\right)$ sebesar 0,377, berarti jika gaya kepemimpinan meningkat 1 satuan maka kinerja karyawan akan meningkat 
0,377 satuan, dengan asumsi variabel GCG dan motivasi konstan. Hasil ini mengindikasikan bahwa gaya kepemimpinan berbanding lurus dengan kinerja karyawan.

Analisis koefisien determinasi dilakukan untuk mengukur seberapa besar variabel bebas mampu menjelaskan perubahan variabel terikatnya. Berdasarkan Tabel 5, nilai Adjusted $R$ Square sebesar 0,740 mempunyai arti bahwa sebesar 74\% variasi kinerja karyawan dipengaruhi oleh variasi GCG, motivasi, dan gaya kepemimpinan, sedangkan $26 \%$ dijelaskan oleh faktor lain yang tidak dimasukkan ke dalam model. Nilai yang tertera digunakan untuk uji kelayakan model analisis atau uji $\mathrm{F}$ (dimana sejumlah variabel $\mathrm{X}$ mempengaruhi variabel $\mathrm{Y}$ ) dengan ketentuan angka profitabilitas yang baik untuk digunakan sebagai model regresi harus $<0,05$. Nilai ini bisa dilihat pada kolom Sig. jika Sig. $<0,05$, maka model analisis dianggap layak. Jika Sig. $>0,05$, maka model analisis dianggap tidak layak. Hasil uji penelitian menunjukkan nila $F$ hitung sebesar 51,152 dengan signifikansi 0,000 yang lebih kecil dai alpha 0,05. Ini menunjukkan model yang digunakan pada penelitian ini adalah layak. GCG, Motivasi, dan Gaya Kepemimpinan dapat digunakan untuk memprediksi kinerja karyawan atau dapat dikatakan bahwa good corporate governance, motivasi, dan gaya kepemimpinan secara bersama-sama berpengaruh terhadap kinerja individual.

Hasil analisis pengaruh Good Corporate Governance pada kinerja karyawan diperoleh nilai koefisien regresi sebesar 0,423 dan nilai sig $t$ sebesar 0,012 . Nilai sig t 0,012 lebih kecil dari 0,05 mengindikasikan bahwa $\mathrm{H}_{1}$ diterima. Hal ini mempunyai arti bahwa Good Corporate Governance berpengaruh positif pada kinerja karyawan sehingga hipotesis pertama dalam penelitian ini diterima. Hal ini berarti bahwa apabila GCG dilakukan dengan baik, maka akan semakin tinggi pula kinerja karyawan Bank BPD Bali. Misalnya, bank harus mengungkapkan informasi secara tepat waktu, memadai, akurat, dan mudah diakses oleh karyawan sesuai dengan prinsip transparansi. Bank harus memiliki ukuran kinerja dari semua jajaran bank serta memiliki rewards and punishment system sesuai dengan prinsip akuntanbilitas. Untuk menjaga kelangsungan usahanya, bank harus berpegang pada prinsip kehati-hatian (prudential banking practices) sesuai dengan prinsip responsibilitas. Bank dalam mengambil keputusan harus obyektif dan bebas dari segala tekanan dari pihak manapun sesuai dengan prinsip independensi, serta bank harus mengungkapkan sistem informasi dengan wajar kepada semua karyawannya sesuai dengan prinsip kewajaran. Hal tersebut mencerminkan tercapainya kinerja karyawan Bank BPD Bali seperti yang diharapkan sesuai dengan Pedoman GCG Perbankan Indonesia Tahun 2004. Sebaliknya, apabila GCG tidak dilakukan dengan baik dalam perusahaan, maka kinerja karyawan akan menurun yang menyebabkan tidak tercapainya kinerja karyawan yang diharapkan. Hasil penelitian ini didukung oleh penelitian Heru et al. (2018) yang menghasilkan bahwa kinerja karyawan dapat dipengaruhi secara signifikan oleh GCG. Sejalan dengan hasil penelitian Puspa \& Yulinda (2019), Dewi et al. (2019) dan Farida (2018) yang menyatakan GCG berpengaruh positif terhadap kinerja.

Pengaruh Motivasi $\left(\mathrm{X}_{2}\right)$ pada kinerja karyawan. Hasil analisis pengaruh Motivasi pada kinerja karyawan diperoleh nilai koefisien regresi sebesar 0,344 dan nilai sig t sebesar 0,031. Nilai sig t 0,031 lebih kecil dari 0,05 mengindikasikan 
bahwa $\mathrm{H}_{2}$ diterima. Hal ini mempunyai arti bahwa Motivasi berpengaruh positif pada kinerja karyawan sehingga hipotesis kedua dalam penelitian ini diterima. Kinerja karyawan meningkat apabila sebuah perusahaan menerapkan pemberian motivasi pada karyawannya agar dapat menyelesaikan pekerjaan yang diberikan tepat waktu sesai dengan standar organisasi yang berlaku, serta mendukung peningkatan karier yang diciptakan oleh karyawan. Motivasi diberikan kepada karyawan bertujuan untuk meningkatkan prestasi kerja atau kinerja karyawan dan tentunya tujuan perusahaan akan tercapai. Hasil penelitian ini didukung oleh penelitian Dewi \& Wibawa (2016) yang menyatakan bahwa motivasi berpengaruh positif pada kinerja karyawan, yang artinya semakin tinggi motivasi maka kinerjanya akan meningkat. Sejalan dengan penelitian yang dilakukan oleh Gusmao \& Riana (2018), Noviani \& Widhiyani (2018), dan Primandaru et al. (2018) yang menyatakan motivasi berpengaruh positif pada kinerja.

Pengaruh Gaya Kepemimpinan $\left(X_{3}\right)$ pada kinerja karyawan. Hasil analisis pengaruh Gaya Kepemimpinan pada kinerja karyawan diperoleh nilai koefisien regresi sebesar 0,377 dan nilai sig t sebesar 0,020. Nilai sig t 0,020 lebih kecil dari 0,05 mengindikasikan bahwa $\mathrm{H}_{3}$ diterima. Hal ini mempunyai arti bahwa Gaya Kepemimpinan berpengaruh positif pada kinerja karyawan sehingga hipotesis ketiga dalam penelitian ini diterima. Kepemimpinan yang tepat dalam sebuah perusahaan akan menghantarkan perusahaan tersebut menuju kepada peningkatan kinerja yang memiliki daya saing tinggi. Pemimpin yang tepat memiliki strategi untuk menunjang pertumbuhan kinerja karyawan. Kepemimpinan yang baik adalah dimana dalam memberi pengaruh, informasi, pengambilan keputusan dan memberi motivasi untuk memajukan perusahaan, serta tidak merugikan karyawan. Gaya kepemimpinan yang baik akan menciptakan suasana yang menyenangkan dan dapat meningkatkan kinerja karyawan. Hasil penelitian ini didukung oleh penelitian Sari et al. (2016) yang menyatakan gaya kepemimpinan, perilaku pemimpin memberikan pengaruh positif dan dapat meningkatkan kinerja karyawan. Selaras dengan penelitian yang dilakukan Karma et al. (2017), Sitio \& Anisykurlillah (2014), dan Wahyuni (2015) menghasilkan gaya kepemimpinan berpengaruh positif pada kinerja.

\section{SIMPULAN}

GCG berpengaruh positif pada kinerja karyawan Bank BPD Bali di Kabupaten Badung. Hal ini menunjukkan bahwa apabila GCG dilakukan dengan baik, maka akan meningkatkan kinerja karyawan Bank BPD Bali Kabupaten Badung. Motivasi berpengaruh positif pada kinerja karyawan Bank BPD Bali di Kabupaten Badung. Hal ini berarti bahwa apabila karyawan diberikan motivasi dengan baik, maka prestasi atau kinerja karyawan akan meningkat dan tentunya tujuan Bank BPD Bali Kabupaten Badung akan tercapai. Gaya Kepemimpinan berpengaruh positif pada kinerja karyawan Bank BPD Bali di Kabupaten Badung. Hal ini berarti bahwa apabila gaya kepemimpinan diterapkan dengan baik, maka akan meningkatkan kinerja karyawan Bank BPD Bali Kabupaten Badung.

Bank BPD Bali sebaiknya selalu menjaga dan meningkatkan penerapan GCG, motivasi, dan gaya kepemimpinan tersebut. Misalnya dalam menjalankan 
fungsinya sebagai perusahaan perbankan, Bank BPD Bali selalu menerapkan tata kelola perusahaan yang berpedoman pada prinsip transparansi, akuntanbilitas, responsibilitas, independensi, dan kewajaran. Memberikan apresiasi berupa bonus, insentif maupun kenaikan jabatan, serta upaya pemimpin membina hubungan yang baik dengan bawahannya guna untuk meningkatkan kinerja karyawannya. Berdasarkan hasil tabel tabulasi kuisioner responden, karyawan Bank BPD Bali di Kabupaten Badung sudah memberikan respon yang sebenarnya, namun ada beberapa karyawan yang masih menyimpang menjawab butir-butir pertanyaan dalam kuisioner tersebut. Penelitian selanjutnya, diharapkan karyawan Bank BPD Bali yang menjadi responden lebih teliti dalam menjawab pertanyaan kuisioner dan memberikan respon sebagaimana kenyataannya. Penelitian ini menggunakan Bank BPD Bali di Kabupaten Badung sebagai tempat penelitian yang terdiri dari 2 kantor cabang dan 7 kantor cabang pembantu dan menggunakan karyawan yang bekerja dibidang kredit dan HAK sebagai sampel penelitian. Penelitian selanjutnya yang ingin menggunakan topik yang serupa, dapat memperluas cakupan penelitian dengan menggunakan Bank BPD Bali di Kabupaten yang berbeda dan Bank Perkreditan Rakyat sebagai tempat penelitian, atau dalam pemilihan sampel menggunakan seluruh karyawan sebagai responden sehingga penelitian dapat lebih tergeneralisasi.

\section{REFERENSI}

Ahmed, A. F., \& Rugami, M. (2019). Corporate Governance and Perfomance of Savings and Credit Cooperative Societies in Kilifi County, Kenya. International Academic Journal of Economics and Finance, 3(3), 61-79.

Amri, S., Haryono, A. T., \& Warso, M. M. (2016). Pengaruh Good Corporate Governance Terhadap Kinerja Karyawan PT Aditec Cakrawiyasa Semarang. Journal of Management.

Cahyani, E., \& Mulyadi, D. (2017). Pengaruh Kepemimpinan dan Motivasi Terhadap Kinerja Pegawai Kantor Camat Lubuklinggau Selatan II Kota Lubuklinggau. INTERPROF (Jurnal Manajemen) Program Studi Magister Manajemen STIE MURA, 3, 60-73.

Dewi, C. I. A. S., \& Wibawa, I. M. A. (2016). Pengaruh Stres Kerja Dan Motivasi Kerja Terhadap Kinerja Karyawan Pada PT. Bank BPD Bali Cabang Ubud. E-Jurnal Manajemen Unud, 5(12), 7583-7606.

Dewi, D. S., \& Mujiati, N. W. (2015). Pengaruh the Big Five Personality dan Kepemimpinan Transformasional Terhadap Kinerja Karyawan di Karma Jimbaran Villa. E-Jurna Manajemen Unud, 4(4), 930-942.

Dewi, D. S., Susbiyani, A., \& Syahfrudin, A. (2019). Pengaruh Penerapan Good Corporate Governance, Total Asset Turn Over dan Kepemilikan Institusional Terhadap Kinerja Keuangan Perusahaan. International Journal of Social Science and Business, 3(4), 473-480.

Dewi, P. C. P., \& Wirasedana, I. W. P. (2018). Pengaruh Komitmen, Kompetensi dan Good Corporate Governance pada Kinerja Keuangan. E-Jurnal Akuntansi Universitas Udayana, 25(2), 1099-1126. https://doi.org/https://doi.org/10.24843/EJA.2018.v25.i02.p11 Pengaruh

Dewi, P. P. E. R., \& Tenaya, A. I. (2017). Pengaruh Penerapan GCG dan Ukuran 
Perusahaan Terhadap Kinerja Keuangan Perbankan di BEI Periode 20132016. E-Jurnal Akuntansi Universitas Udayana, 21(1), 310-329.

Farida, A. (2018). Pengaruh Penerapan Good Corporate Governance Dan Pengungkapan Islamic Social Reporting Terhadap Kinerja Keuangan Perbankan Syariah Di Indonesia. Jurnal Ekonomi Islam, 10(1), 31-42.

Gultom, D. K. (2014). Pengaruh Budaya Organisasi Perusahaan dan Motivasi Terhadap Kinerja Karyawan Pada PT. Perusahaan Gas Negara (Persero) Tbk Medan. Jurnal Manajemen \& Bisnis, 14(02), 176-184.

Gunawan, T., \& Sutiono, F. (2018). Pengujian Good Corporate Governance dan Ukuran Perusahaan terhadap Kinerja Perusahaan. Jurnal Online Insan Akuntan, 3(1), 21-30.

Gusmao, J. F., \& Riana, G. (2018). Pengaruh Kompensasi Terhadap Motivasi Dan Kinerja Pegawai Administrasi Di Dinas Pendidikan Distrik Baucau Timor Leste. Jurnal Buletin Studi Ekonomi, 23(1), 138-153.

Heru, F. P. R., Susilo, H., \& Aini, E. K. (2018). Pengaruh Organizational Citizenship Behavior (OCB) Dan Good Corporate Governance (GCG) Terhadap Kinerja Karyawan (Studi pada Karyawan PT. TASPEN (Persero) Kantor Cabang Malang). Jurnal Administrasi Bisnis (JAB), 55(2), 160-166.

Jensen, M. C., \& Meckling, W. H. (1976). Theory of the firm: Managerial behavior, agency costs and ownership structure. Journal of Financial Economics. https:/ /doi.org/10.1016/0304-405X(76)90026-X

Junaidi, R., \& Susanti, F. (2006). Pengaruh Gaya Kepemimpinan dan Budaya Organisasi Terhadap Kinerja Pegawai Pada UPTD Baltekkomdik Dinas Pendidikan Provinsi Sumatera Barat, 1-13.

Juniantara, I. W., \& Riana, I. G. (2015). Pengaruh Motivasi dan Kepuasan Kerja Terhadap Kinerja Karyawan Koperasi di Denpasar. E-Jurnal Ekonomi Dan Bisnis Universitas Udayana, 4(9), 611-628.

Karma, K. F. A., Yasa, G. W., \& Ratnadi, N. M. D. (2016). Pengaruh Gaya Kepemimpinan Situasional, Budaya Organisasi Dan Motivasi Pada Kinerja Karyawan Di PT Bank Pembangunan Daerah Bali Cabang Badung. E-Jurnal Ekonomi Dan Bisnis Universitas Udayana.

Kesuma, B., \& Syamsuddin, H. (2019). Pengaruh Gaya Kepemimpinan Demokratis dan Motivasi Terhadap Kinerja Karyawan PT.Panin Bank Cabang Atmo Palembang. Jurnal Ecoment Global, 4(2), 103-117.

Mahadewi, I. A. A., \& Putri, I. G. A. M. A. D. (2019). Pengaruh Penerapan Prinsip-Prinsip Good Governance Terhadap Kinerja Pada Rumah Sakit Di Kota Denpasar. E-Jurnal Akuntansi Universitas Udayana, 27(1), 568-593. https://doi.org/https:// doi.org/10.24843/EJA.2019.v27.i01.p21

Noviani, N. L. K. S., \& Widhiyani, N. L. S. (2018). Pengaruh Gaya Kepemimpinan Situasional, Motivasi dan Pelatihan Pada Kinerja Karyawan di Koperasi Pasar Srinadi Klungkung. E-Jurnal Akuntansi Universitas Udayana, 25(3), 2212-2241. https://doi.org/https://doi.org/10.24843/EJA.2018.v25.i03.p22

Nurcahyani, N. M., \& Adnyani, I. G. A. D. (2016). Pengaruh Kompensasi dan Motivasi Terhadap Kinerja Karyawan Dengan Kepuasan Kerja Sebagai Variabel Intervening. E-Jurnal Manajemen Unud, 5(1), 500-532.

Pratiwi, P. D. A., \& Budiartha, I. K. (2018). Pengaruh Penerapan Good Corporate Governance dan Gaya Kepemimpinan pada Kinerja Keuangan. E-Jurnal 
Akuntansi Universitas Udayana, 24(3), 2226-2246. https://doi.org/https://doi.org/10.24843/EJA.2018.v24.i03.p22

Primandaru, D. L., Tobing, D. S. K., \& Prihatini, D. (2018). Pengaruh Motivasi Kerja Dan Lingkungan Kerja Terhadap Kepuasan Kerja, Disiplin Kerja Dan Kinerja Karyawan PT Kereta Api Indonesia (Persero) Daop IX Jember. Jurnal Bisnis Dan Manajemen, 12(2), 204-211.

Puspa, S. D., \& Yulinda. (2019). Pengaruh Penerapan Prinsip Good Corporate Governance Terhadap Kinerja Non-Keuangan Pada Perusahaan B'right Pln Batam. Journal Of Applied Managerial Accounting, 3(1), 66-80.

Puspitha, M. Y., \& Sujana, I. K. (2016). Budaya Organisasi Pemoderasi Pengaruh Prinsip Good Corporate Governance Pada Kinerja Perusahaan Berbasis Balanced Scorecard. E-Jurnal Akuntansi Universitas Udayana, 14(3), 19782012.

Putri, I. A. M. K., \& Badera, I. D. N. (2019). Pengaruh Komitmen Organisasi dan Motivasi Kerja Terhadap Kinerja Auditor Dengan Tindakan Supervisi Sebagai Variabel Moderasi. E-Jurnal Akuntansi Universitas Udayana, 26(2), 1215-1240. https:// doi.org/https://doi.org/10.24843/EJA.2019.v26.i02.p14

Putri, N. K. D. Y., \& Putra, I. M. P. D. (2017). Pengaruh Prinsip-Prinsip Good Corporate Governance, Motivasi, dan Budaya Organisasi Terhadap Kinerja Karyawan. E-Jurnal Akuntansi Universitas Udayana, 21(2), 1660-1688. https://doi.org/https://doi.org/10.24843/EJA.2017.v21.i02.p29

Sari, E. K., Minarsih, M. M., \& Gagah, E. (2016). Analisis Pengaruh Gaya Kepemimpinan, Motivasi, Kualitas Kehidupan Kerja Terhadap Kinerja Karyawan (Studi Kasus Pada PD.BKK Dempet Kabupaten Demak). Journal Of Management, 2(2).

Sari, N. (2015). Pengaruh Gaya Kepemimpinan dan Budaya Organisasi Terhadap Kinerja Dosen Pada Politeknik Swasta (Politeknik Anika, Politeknik Akamigas dan Politeknik Darussalam) di Palembang. Jurnal Adminika, 1(2), 111-127.

Setiawan, K. A., \& Mujiati, N. W. (2016). Pengaruh Gaya Kepemimpinan dan Kompensasi Terhadap Kinerja Karyawan PT. Astra Honda Nusa Dua Kabupaten Badung. E-Jurnal Manajemen Unud, 5(12), 7956-7983.

Setyawan, K. M., \& Putri, I. G. A. M. A. D. (2013). Pengaruh Good Corporate Governance Terhadap Kinerja Keuangan Lembaga Perkreditan Desa di Kecamatan Mengwi Kabupaten Badung. E-Jurnal Akuntansi Universitas Udayana, 5(3), 586-598.

Shahzadi, I., Javed, A., Pirzada, S. S., Nasreen, S., \& Khanam, F. (2014). Impact of Employee Motivation on Employee Performance. European Journal of Business and Management, 6(23), 159-167.

Sidanti, H. (2015). Pengaruh Lingkungan Kerja, Disiplin Kerja dan Motivasi Kerja Terhadap Kinerja Pegawai Negeri Sipil di Sekretariat DPRD Kabupaten Madiun. Jurnal JIBEKA, 9(1), 44-53.

Sitio, R., \& Anisykurlillah, I. (2014). Pengaruh Pemahaman Good Governance, Gaya Kepemimpinan, Budaya Organisasi Dan Struktur Audit Terhadap Kinerja Auditor (Studi Empiris Pada Kantor Akuntan Publik Di Kota Semarang). Accounting Analysis Journal, 3(3), 301-309.

Sudja, N. A. P., \& Mujiati, N. W. (2017). Pengaruh Karakteristik Pekerjaan, 
Penempatan dan Gaya Kepemimpinan Terhadap Kinerja Karyawan Pada Sekretariat Daerah Kota Denpasar. E-Jurnal Manajemen Unud, 6(1), 550-578.

Tertius, M. A., \& Christiawan, Y. J. (2015). Pengaruh Good Corporate Governance terhadap Kinerja Perusahaan pada Sektor Keuangan. Business Accounting Rivew, 3(1), 223-232.

Tulhusnah, L., Sularso, A., \& Fathorrazi, M. (2018). Pengaruh Kepemimpinan dan Motivasi Kerja Terhadap Kepuasan Kerja dan Kinerja Pegawai Pada Kantor Badan Pertanahan Nasional Kabupaten Situbondo. Jurnal Ekonomi Dan Bisnis GROWTH (JEBG), 16(1), 18-29.

Wahyuni, E. (2015). Pengaruh Budaya Organisasi Dan Gaya Kepemimpinan Terhadap Kinerja Pegawai Bagian Keuangan Organisasi Sektor Publik Dengan Motivasi Kerja Sebagai Variabel Intervening (Studi Kasus Pada Pegawai Pemerintah Kota Tasikmalaya). Jurnal Nominal, 4(1), 96-112.

Wiguna, I. D. G. E. C. (2015). Pengaruh Gaya Kepemimpinan, Komunikasi, Pendidikan dan Pelatihan Terhadap Kinerja Karyawan Pada PT. PLN (Persero) Distribusi Bali Area Bali Selatan. E-Jurnal Manajemen Unud, 4(7), 2085-2094. 